\title{
Assertiveness of Bullying Victims in Elementary School
}

\author{
Syarifah Ivonesti ${ }^{1}$ and Syarifah Hidayah Fatriah ${ }^{2 *}$ \\ ${ }^{1}$ Faculty of Psychology stain Bengkalis, Riau Province, Indonesia \\ ${ }^{2}$ Departement of Forensic Medicine and Medicolegal Faculty of Medicine, University of Riau, Indonesia
}

Received: 眥February 03, 2018; Published: 澅 February 09, 2018

*Corresponding author: Syarifah Hidayah Fatriah, Departement of Forensic Medicine and Medicolegal Faculty of Medicine, University of Riau, Indonesia

\begin{abstract}
Forensic Science and Forensic Psychiatry plays a role in the developement of Psychology in Children and Psychology Education. Forensic science is related with physical examination in victims who have suffered from physical bullying. Pyschiatrist are related to victims who have suffered from verbal and psychological bullying.
\end{abstract}

Keywords: Forensic Science; Psychology; Bullying; Elementary School

\section{Introduction}

Bullying, according to Lidenberg [1] Is an agressive behaviour with an imbalance of power between the prepertrator (bully) and victim, which is done repeatedly by a child or a group of children. Its purpose is to annoy another child of of the same age. The difference between bullying and other agressive behaviours is that the frequency of bullying is done repeatedly, and the relationship between the prepertrator and victim, where the victim is usually a specific target who is dominated by the power of the prepertrator [2] In elementary schools, there are many types of direct bullying, such as physical (ex: hitting, punching) and verbal (ex: threats) bullying. Craig. According to [3], there are three types of bullying:

a) Pyhsical Bullying, ex: taking the victims belongings, hitting/punching/kicking/pinching the victim, destroying the victims belongings etc;

b) Verbal Bullying, ex: calling names or nicknames, making fun of the victim, mocking the victim,

c) Pyschological bullying, ex: spreading rumours about the victim, rejecting the victim in a certain group.

In Persecuted Even on the Playground of the Liberation Magazine, Richard Werrly stated that $10 \%$ of students in Japan suffer from stress due to the bullying they recieves, and at least attempted suicide once. Japan Education Department estimated 26.000 elementary and junior high school students skip school because of the the bullying that occured to them at school SEJIWA. The same problem is also occured in Europe and Australia [4]. It is estimated that from 15.686 students, $29,9 \%$ experience bullying with $13 \%$ as the bully, $10,6 \%$ as the victime and $6,3 \%$ as both the bully and victim. Nansel, dalam Raskauskas , Stoltz, A survey by Yayasan Semai Jiwa Amini (SEJIWA) hows that bullying in Indonesia between 2005-2007, occured in children between 9-19 years old, and 30 victims that died as a result from bullying. Ratna Juwita studied 1500 children in three cities Surabaya, Yogyakarta and Jakarta, the result showed that $70 \%$ of bullying occurs in school [5].

Bullying victims, according to Orpines [6] are individuals that recieve agressive behaviours repeatedly. One of the reason why a student or individual becomes a victim to bullying is said to have a low assertiveness. This is supported by a pilot study by Saripah [7], where 526 elementary students in five regions and cities in West Java showed that bullying has become a major sosial problem in elementary students (42,59\%), and the result showed that bullying victims have a love assertiveness.

A victim of bullying can't defend themselves assertively $[8,9]$. The tend to obey the bully, cry easly and passively recieve the agressive behaviour given to them. This Shows that bullying victims have a low assertiveness [10]. Assertiveness itself is the quality of being self-assured, confident and maintaining their rights without being aggressive or harming other people [10]. Assertiveness, according to, is defined to the ability to express feeling, choose 
how to behave, maintain their rights, increase their self respect and know when and what to speak. Other opinions such as Alberti and Emmons, defined assertiveness as a behaviour that allows an individual to act as they want, maintain themselves without a worry, express their feeling honestly and comfortably or use their rights without violating the right of others [11]. Pyschological aspects of assertiveness according to Sheffield [12], is making a request, cutting off a conversation to uphold their rights, saying no, and ignoring a statement.

\section{Making at Request}

This way is used by an individual when bullyed to state what they want or a request to the bully without violating each others rights. This ability can be done before stating a request, the individual (student) must know what they want first. In order to state the request well, the individu (student) must practice how to make that request. Practice should start by using small statements, such as: "this is mine, i want you to give it back to me".

\section{Cutting of a Convesation to Uphold their Rights}

This can be done by students who experience bullying. Cutting of a conversation si done when the bully is seducing the victim to get what he/she wants. It is also a way to uphold the victims rights when the victim doesnt want to obey what the bully wants. By consistenly cutting of the conversation, it is hoped that the bully will give up forcing the victim to do something they dont want, for example: i know you dont have a pencil, but this is my pencil and i want my pencil back". If the bully keeps forcing the victim, the victim must be more persistent until the bully finally gives up.

\section{Saying "NO"}

Saying no is a way for the victim state out that they are refusing the request of the bully. Here, the victim must understand that everyone has the right to say "No". This is to make the victim aware of their rights and so that they dont feel guilty for declining the request from the bully. When saying "No", the victim must show an assertive body posture, for example: standing straight up, not smiling and making eye contact with the bully. This too needs practice. Practice can be done with friends, peers, family or even in front of the mirror.

\section{Ignoring a Statement}

Ignorning a statement is another way for the stand up to the bully. Here, the victim does not reply to the statement given or answer with insulting words. The victim should not show any anger towards the statement given by the bully. When the victim finds a statement is true, he/she may answer with "thats true". But when the statement given is not true, the victim should answer with "you might be right" atau " that may be true, or maybe not". Whatever answer is given, it should be said calmly. This type of reply is hoped to make bully not increase the state of bullying given to the victime.

Theoritically and empirically, a bully has a history of being bullyed themselves [13]. A bully tends to have agressive behaviour and a lack of empathy. Sciara, Olweus, Coloroso, Saripah Another effect of bullying is that the victim usually more suspectible to disease, experiencing academic barriers such as fear in going to school and decreasing in academic prestiges, longterm effects may include suicide, anxiety, low selfesteem and depression. Hawker Boulton, Mc Daugall, Vilancourt, Hymel [14], where as students who are victims of bullying who give an agressive response that suffer from bullying will have difficulty adjusting psychologically, such as antisosial behaviour, social and emotional. Glover, Gough, Johnson, Cartwright, dalam Smith [15,16].

\section{Conclusion}

One of the reasons why bullying occurs in elementary school is due to the lack of assertiveness, not only from the victim but also from the bully. Assertiveness is important because it can help the children to have a better social interaction with friends, family, teachers and social enviroment.

\section{References}

1. Lindenberg S, Oldhinkel AL, Winter AJ, Verhulst FC, Ormel J (2005) Bullying and Victimization in Elemanary Schools: A Comparison of Bullies, Victim, Bully/Victim And Uninvolved Preadolecent. Dev Psychol 51(4): 672-682.

2. Coutrney ML, Cohen R, Deptula DP, Kitzmann KM (2003) An Experimental Analysis of Chidren's Dislike of Aggressor and Victims. Social Development 12(1): 46-66.

3. Baldy AC, Farrington D (2004) Evaluation of an Intervetion Program for the Reduction of Bullying and Victimization in Schools. Aggressive Behavior 30: 1-15.

4. Smith DJ, Schneinder HB, Smith KP, Ananiadou K (2004) The Effectivenes of Whole-School Antibullying Programs: A Syntesis of Evaluation Research Journal of School Psychology Review 33(4): 547-560.

5. Suyatno (2008) Guru Perlu Tahu Bullying (Tindak Kekerasan) di sekolah. Gardu Guru

6. Orpinas P, Horne AM (2006) Bullying Preventing, Creating A Positive School Climate And Developing Social Competence. American Psychological Association Washington, USA.

7. Saripah I (2010) Model Konseling Kognitif Perilaku Untuk Menangulangi Bullying Siswa (Studi Pengembangan Model Konseling pada Siswa Sekolah Dasar di Beberapa Kabupaten dan Kota di Jawa Barat Tahun Ajaran. Universitas Pendidikan, Indonesia.

8. Fox CL, Bolton MJ (2005) The Social Problems of Victim of Bullying: Self Peer, and Teacher Perception. Br J Educ Psychol 75: 313-328.

9. Shieffeld J (2001) Kindscape ZAP Asertivenees Training Year 2 Report.

10. Bower dan Bower (1992)

11. Marini L, Andriani E (2005) Perbedaan Asertivitas Remaja Ditinjau Dari Pola Asuh Orang Tua. Psikologika Fakultas Kedokteran Universitas Sumatra Utara 1(2): 46-53.

12. Sheffield J (2001) Asertiveness for Chidren.

13. Holt MK, Finkelhor D, Kantor GK (2007) Hidden Form of Victimization in Elementary Students Involved in Bullying Family/Research Laboratory and Crimes against Children Research Center, University of New Hampshire. School Psychology Review 36: 345-360.

14. Swearer SM, Espelage DL, Vaillacourt T, Hymel S (2010) What Can Be Done About School Bullying? Linking Research to Educational Practice. Educational Researcher 39(1): 38-47. 
15. Raskauskas J, Stoltz AD (2007) Involment in Traditional and Electronic Bullying Among Adolescent. Dev Psychol 43(3): 564-575.
16. Yayasan Semai Jiwa Amini (SEJIWA) (2008) Mengatasi Kekerasan di Lingkungan Sekitar Anak, Grasindo: Jakarta, Indonesia

\section{(C) \\ This work is licensed under Creative Commons Attribution 4.0 License}

To Submit Your Article Click Here:

Submit Article

DOI: $10.32474 /$ PRJFGS.2018.01.000104

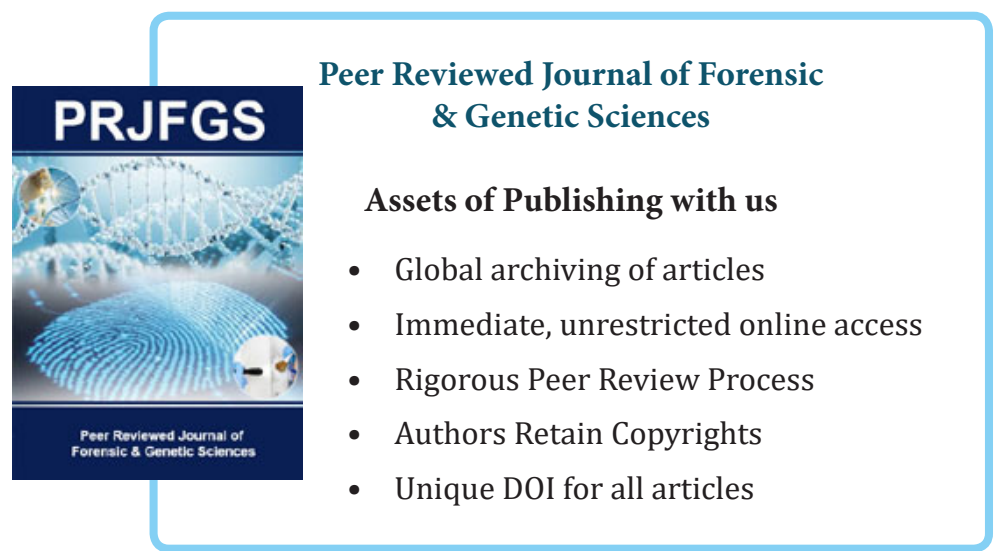

